\title{
Thinning and slowdown of Greenland's Mittivakkat Gletscher
}

S. H. Mernild ${ }^{1}$, N. T. Knudsen ${ }^{2}$, M. J. Hoffman ${ }^{3}$, J. C. Yde ${ }^{4}$, W. H. Lipscomb ${ }^{2}$, E. Hanna ${ }^{5}$, J. K. Malmros ${ }^{6}$, and R. S. Fausto ${ }^{7}$

${ }^{1}$ Climate, Ocean, and Sea Ice Modeling Group, Computational Physics and Methods, Los Alamos National Laboratory, New Mexico, USA

${ }^{2}$ Department of Geoscience, Aarhus University, Aarhus, Denmark

${ }^{3}$ Climate, Ocean, and Sea Ice Modeling Group, Fluid Dynamics and Solid Mechanics, Los Alamos National Laboratory, New Mexico, USA

${ }^{4}$ Sogn og Fjordane University College, Sogndal, Norway

${ }^{5}$ Department of Geography, University of Sheffield, UK

${ }^{6}$ Centro de Estudios Científicos, Valdivia, Chile

${ }^{7}$ Geological Survey of Denmark and Greenland, Denmark

Received: 7 September 2012 - Accepted: 26 September 2012 - Published: 12 October 2012

Correspondence to: S. H. Mernild (mernild@lanl.gov)

Published by Copernicus Publications on behalf of the European Geosciences Union.

\section{$6,4387-4415,2012$}

Thinning and slowdown of Greenland's Mittivakkat Gletscher

S. H. Mernild et al.

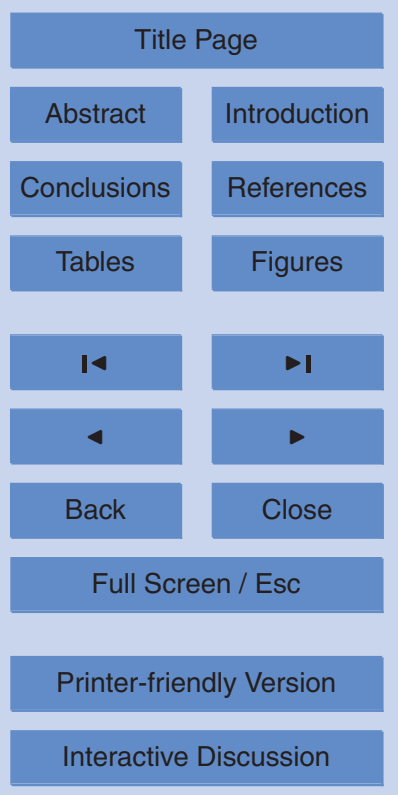




\section{Abstract}

Here, we document changes for the Mittivakkat Gletscher, the glacier in Greenland (disconnected to the Greenland Ice Sheet, GrIS) having the longest observed mass balance and surface velocity time series (since 1995). Between 1986 and 2011, this

5 glacier decreased by $15 \%$ in mean ice thickness and $30 \%$ in volume. We attribute these changes to summer warming and less winter snowfall. The vertical strain was able to compensate about $60 \%$ of the elevation change due to surface mass balance (SMB) in the lower part, and about $25 \%$ in the upper part. The annual mean ice surface velocity decreased by $30 \%$, likely as a dynamic effect of ice thinning. Mittivakkat Gletscher summer surface velocities were on average $50-60 \%$ above winter background values, and up to $160 \%$ higher during peak velocity events.

\section{Introduction}

In recent decades, glaciers have thinned and receded in many regions of the world (Oerlemans et al., 2007; Cogley, 2012; Leclercq and Oerlemans, 2012). The contribu15 tion of local glacier mass loss to sea-level rise is comparable to that from the Greenland and Antarctic ice sheets and has increased in recent decades (Kaser et al., 2006; Meier et al., 2007; Cogley, 2012). Thousands of individual glaciers are located peripheral to the GrIS, covering an area of $89273 \pm 2767 \mathrm{~km}^{2}$ (Rastner et al., 2012), compared with $\sim 1.7 \times 10^{6} \mathrm{~km}^{2}$ for the whole ice sheet (Kargel et al., 2012). Our knowledge of the 20 morphological characteristics, ice dynamics, and climate sensitivity of these glaciers is limited. Glacier mass balance studies often exclude the Greenland peripheral glacier contribution to sea-level rise (e.g. Jacob et al., 2012), even though studies by Yde and Knudsen (2007), Kargel et al. (2012), and Mernild et al. (2012) have documented substantial glacier area recession on Disko Island (69-70 N; West Greenland), in Central

25 East Greenland $\left(68-72^{\circ} \mathrm{N}\right)$, and in the Ammassalik region $\left(65^{\circ} \mathrm{N}\right.$; Southeast Greenland), respectively. Not only is the glacier area decreasing, but also the annual surface

\section{Thinning and slowdown of Greenland's Mittivakkat Gletscher}

S. H. Mernild et al.

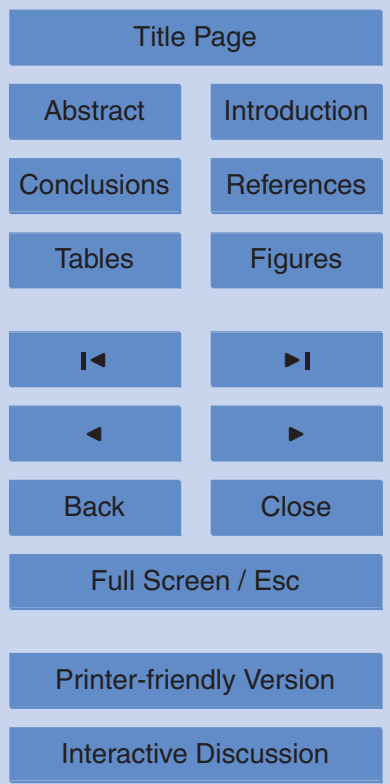


melt extent and the amount of surface melting and freshwater runoff from peripheral glaciers have increased during the past several decades (e.g. Mernild and Hasholt, 2006; Kargel et al., 2012). This trend concords with observations and modeling of runoff from the GrIS (Hanna et al., 2008, 2012; Mernild et al., 2010; Mernild and Liston, 5 2012), where increased surface melting influences glacier dynamics through changes in subglacial hydrology (e.g. van der Wal et al., 2008; Mernild and Hasholt, 2009; Sundal et al., 2011).

Mittivakkat Gletscher (henceforth MG; Fig. 1), located in the Ammassalik region, is Greenland's only peripheral glacier for which there exist surface mass balance (SMB) 10 records and surface velocity measurements (since 1995), and aerial photos, satellite margin and area observations (since 1900) (Mernild et al., 2011a, 2012). This study analyzes spatial changes in MG's SMB (winter, summer, and annual net mass balances), and quantify the decrease in MG's ice thickness, volume, and surface velocity during a 25-yr period of climate warming (1986-2011). These new results supplement 15 a previous study of MG by Mernild et al. (2011a), where the focus was on the relations between frontal glacier recession, annual net mass balance and accumulation area ratio (AAR) conditions related to out of balance conditions.

\section{Study area}

Mittivakkat Gletscher $\left(65^{\circ} 42^{\prime} \mathrm{N}, 37^{\circ} 48^{\prime} \mathrm{W} ; 26.2 \mathrm{~km}^{2}\right)$ is located in the Ammassalik re20 mal conditions near $0^{\circ} \mathrm{C}$, apart from the upper few meters that undergo seasonal tem-
perature variations (Knudsen and Hasholt, 1999). Observations of both glacier front fluctuations (since the maximum Little Ice Age, LIA, extension around 1900) and SMB (since 1995) exist. Since the LIA the MG has undergone almost continuous retreat 25 (Knudsen and Hasholt, 1999; Knudsen et al., 2008; Mernild et al., 2011a). During $1986-2011$ the glacier area decreased by $18 \%$, from $31.6 \mathrm{~km}^{2}(1986)$ to $29.5 \mathrm{~km}^{2}$ (1999) to $26.2 \mathrm{~km}^{2}$ (2011) (Mernild et al., 2012), and the mean surface slope increased

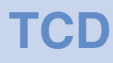

$6,4387-4415,2012$

Thinning and slowdown of Greenland's Mittivakkat Gletscher

S. H. Mernild et al.

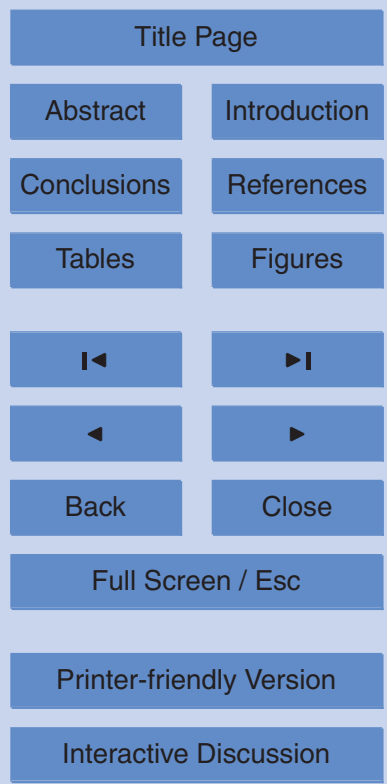


from $0.095 \mathrm{~m} \mathrm{~m}^{-1}$ (equals $5.4^{\circ}$ ) to $0.104 \mathrm{~mm}^{-1}\left(5.9^{\circ}\right)$. The area retreat follows the overall trend for the Ammassalik region, where the glacier area decreased by $27 \pm 24 \%$ during this period (Mernild et al., 2012) (here and below, the error term is the standard deviation).

5 For MG the annual SMB has been observed for $16 \mathrm{yr}$ since 1995/1996 and the winter and summer balances for $10 \mathrm{yr}$. The mean annual net mass balance is $-0.97 \pm 0.75 \mathrm{~m}$ water equivalent (w.e.) $\mathrm{yr}^{-1}$, with a mean winter balance of $1.18 \pm 0.19 \mathrm{mw}^{\mathrm{w}}$.e. $\mathrm{yr}^{-1}$ and a mean summer balance of $-1.94 \pm 0.38 \mathrm{mw}^{\mathrm{e}} \mathrm{yr}^{-1}$. The net annual SMB has decreased on average by 0.09 mw.e. $\mathrm{yr}^{-2}\left(r^{2}=0.36 ; p<0.01\right.$, significant; where $r^{2}$ is 10 the explained variance and $p$ is level of significance). The explained variance in the winter and summer balances were $r^{2}=0.34 ; p<0.05$ and $r^{2}=0.01 ; p>0.25$, respectively: winter and summer balances were not observed during several years in the later part of the record with highly negative annual SMB. The net balance in 2010/2011 was a record setting $-2.45 \mathrm{~m}$ w.e.: about 2 standard deviations below the mean and $0.29 \mathrm{~m}$ w.e. more negative than the previous observed record low mass balance in 2009/2010 (Mernild et al., 2011b).

Since 1995 the equilibrium line altitude (ELA; the spatially averaged elevation of the equilibrium line, defined as the set of points on the glacier surface where the net mass balance is zero) has risen from around $500 \mathrm{~m}$ above sea level (a.s.l.) to $750 \mathrm{~m}$ a.s.l. 20 (Mernild et al., 2011a), where MG faced negative mass balance at all elevations for six years: $1997 / 1998,2000 / 2001,2004 / 2005,2006 / 2007,2009 / 2010$, and 2010/2011. The average accumulation area ratio (AAR, the ratio of the accumulation area to the area of the entire glacier) is about 0.15 , indicating that $M G$ is significantly out of balance with the present climate. The glacier will likely lose at least $70 \%$ of its current area and $80 \%$ of its current volume even in the absence of further climate warming (Mernild et al., 2011a).

\section{TCD}

$6,4387-4415,2012$

Thinning and slowdown of Greenland's Mittivakkat Gletscher

S. H. Mernild et al.

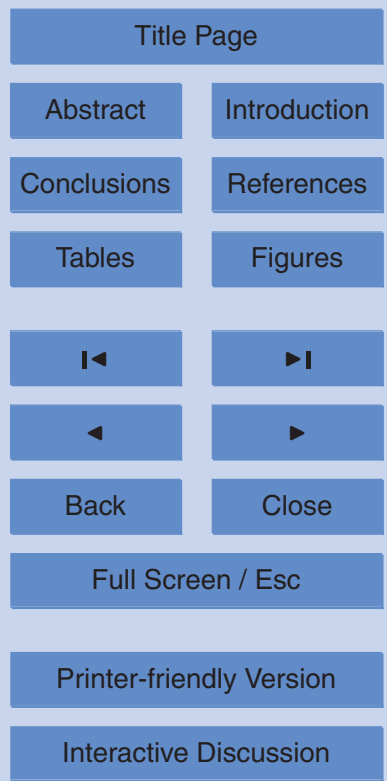




\section{Data and methods}

\subsection{Thickness and volume}

In 1994 the MG surface elevation, bed topography, and ice thickness were estimated based on monopulse radio-echo soundings (Knudsen and Hasholt, 1999). The mean

5 MG ice thickness $(115 \mathrm{~m})$ was derived from measurements at 450 positions, spaced about $100 \mathrm{~m}$ apart along profiles running across the glacier, and about $300 \mathrm{~m}$ apart along the flow line with a vertical spacing of $50 \mathrm{~m}$. The error of the measured ice thicknesses was estimated to be less than $\pm 5 \mathrm{~m}$ (Knudsen and Hasholt, 1999), giving a relative uncertainty of less than $5 \%$ for the mean 1994 ice thickness $(115 \mathrm{~m})$.

In 1995 a glacier observation program was initiated to measure MG's annual SMB and to map changes in ice thickness. A network of stakes was used to measure net summer ablation (Fig. 1) based on the direct glaciological method (Østrem and Brugman, 1991): the vertical inaccuracy in observed annual stake measurements has been estimated to be less than $5 \mathrm{~cm}$. Measurements were obtained at 59 stakes covering $1516.3 \mathrm{~km}^{2}$ of the MG, excluding the crevassed area in the southeastern part of the glacier (this omission is not likely to bias the results, since the surface of the crevassed area follows the general hypsometric distribution in the upper part of MG, Mernild et al., 2006, 2008a) (for more information about the direct glaciological method and uncertainties, see Mernild et al., 2011a). Since its establishment the stake network has moved slowly down the glacier by $50-275 \mathrm{~m}$ (based on calculations, this movement has an insignificant impact on estimates of the mean annual surface velocity). The winter balance was calculated as the difference between the net annual balance and the summer balance. The mass balance observations are considered to be accurate within $15 \%$ for the MG (Knudsen and Hasholt, 2004), which is within the uncertainty range suggested

The MG ice volume was calculated for 1986, 1999, and 2011 (the same years as the area extent derived from Landsat imagery, Mernild et al., 2012) based on the satellitederived glacier extent multiplied by the mean ice thickness. The mean ice thicknesses

6, 4387-4415, 2012

Thinning and slowdown of Greenland's Mittivakkat Gletscher

S. H. Mernild et al.

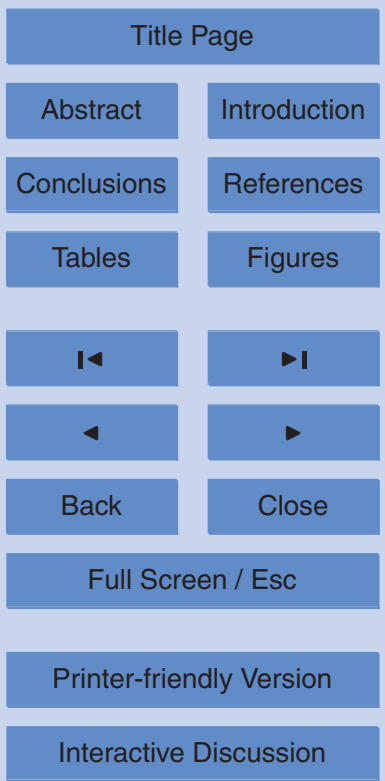

4391 
for 1999 and 2011 were calculated from the observed 1994 mean thickness minus the cumulative observed mass balance. The 2011 calculated MG thickness was compared against monopulse radio-echo sounding estimated MG thicknesses at two crosssection profiles (both located in the ablation zone) in 2011 to confirm that the calcula-

5 tions were near the observations (Fig. 2). At the stake locations (seven stakes) at the two cross-section profiles the mean difference in ice thickness between calculations and radio-echo soundings was on average $2 \mathrm{~m}$, indicating a reasonable agreement (Fig. 2). The 1986 mean ice thickness was estimated by adding to the 1994 mean thickness the cumulative mass balance during 1986-1994, based on modeled MG annual 10 mass balance data from Mernild et al. (2008b); herein the calculated MG annual mass balance was compared against observed mass balance for a control period 1995/1996 to $2003 / 2004$, indicating a $r^{2}$ value of 0.71 (significant, $p<0.01$ ) and a difference less than $0.01 \mathrm{~m}$ between observed and calculated mass balance values. The 1986-1994 calculation method was extended back to 1981 , where the mean calculated surface el15 evation was compared to the 1981 map $(1: 20000)$ digitized mean surface topography (Knudsen and Hasholt, 1999), indicating an average difference of 2-4 m (not illustrated in this study).

The MG surface slope was calculated for both 1996 and 2011 for the longitudinal profile (illustrated in Fig. 5b), for the stakes: 31, 40, 50, 60, 70, 80, 107, 110, 120, 130, 20 and 140.

\subsection{Surface ice velocity and thickness changes}

Each stake position (Fig. 1) was measured annually; varying from 47 stakes in 1998 and 2001 to 19 stakes for the years 2008 through 2011: 19 stakes were measured continuously throughout the period 1995/1996 to 2010/2011. Before 2004, the stake 25 positions were measured by topographic surveys using a theodolite (Kern) with an Electro-optical Distance Meter, having a horizontal uncertainty of less than $\pm 1 \mathrm{~m}$. After 2004, stake position was based on a portable single-frequency GPS (Garmin GPS 12 $\mathrm{XL}$ ) with a relative uncertainty (standard deviation) of about $\pm 2 \mathrm{~m}$; this value is based on

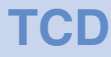

$6,4387-4415,2012$

Thinning and slowdown of Greenland's Mittivakkat Gletscher

S. H. Mernild et al.

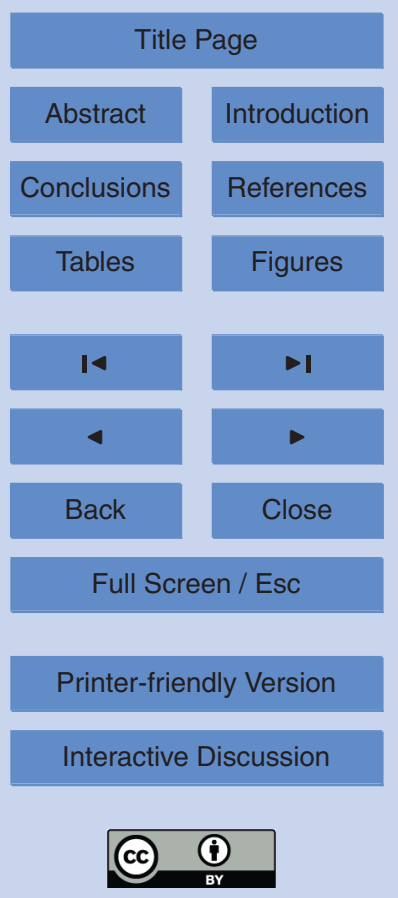


repeated fixed station measurements with the same instrument during several years. The annual stake positions were used to calculate the spatial mean surface velocity field for the MG.

Also, a continuous ice surface velocity time series was obtained from a dual5 frequency GPS-receiver (Javad Laxon GGD160T, operated by the Geological Survey of Denmark and Greenland) positioned near the center of MG (Fig. 1). This time series was used to determine the seasonal variability in ice surface velocity. However, we have access to data only from May 2004 through July 2005 (when the GPS-receiver was located at elevations from 462 to $455 \mathrm{~m}$ a.s.l.) and from March 2009 through Autime series were on average around $3 \mathrm{~mm}$ and $6 \mathrm{~mm}$, respectively.

Thickness changes, $\mathrm{d} h / \mathrm{d} t$, at a point on the glacier are a combination of SMB and vertical strain, and they can be described by continuity (Cuffey and Patterson, 2010) approximately as:

$\mathrm{d} h / \mathrm{d} t=b-u_{\mathrm{s}} \tan \alpha+w_{\mathrm{s}}$

where $b$ is the SMB, $u_{\mathrm{s}}$ is the horizontal surface velocity, $\alpha$ is the surface slope, and $w_{\mathrm{s}}$ is the vertical velocity of a fixed point on the glacier (e.g. the top of a stake). However, our surveys measured the position of the ice surface at each stake, and therefore our observed vertical velocity includes the SMB. Thus, we calculate thickness changes as:

$\mathrm{d} h / \mathrm{d} t=w_{\mathrm{obs}}-u_{\mathrm{s}} \tan \alpha$

where $w_{\text {obs }}$ is the observed vertical velocity measured as the height difference between two successive surveys of the ice surface elevation at the position of a stake. We separate the component of thickness change due to vertical strain rate (emergence velocity; $w_{\mathrm{e}}$ ) as:

$w_{\mathrm{e}}=\mathrm{d} h / \mathrm{d} t-b$

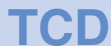

6, 4387-4415, 2012

Thinning and slowdown of

Greenland's

Mittivakkat Gletscher

S. H. Mernild et al.

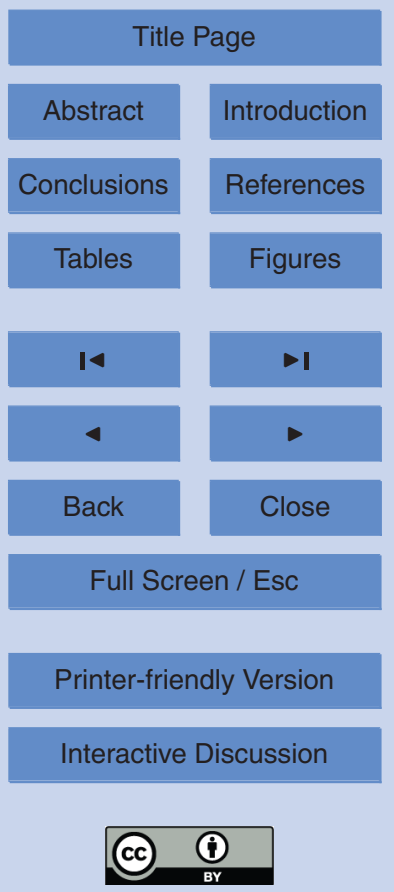




\subsection{Meteorological data}

Meteorological conditions at MG were obtained from automated weather stations located on a small nunatak (515 m a.s.l.; operated by University of Copenhagen) (Mernild et al., 2008c) a few hundred meters below the present ELA, and in the outskirts of

5 Tasiilaq (44 $\mathrm{m}$ a.s.l.; operated by Danish Meteorological Institute) (DMI, 2011), located $15 \mathrm{~km}$ to the southeast of MG. Both observed air temperature and precipitation were compared to seasonal and annual changes in the MG ice surface velocity.

\section{Results and discussion}

\subsection{Spatial surface mass balance and thickness changes}

10 Figure 3 illustrates the mean spatial variations in winter, summer, and annual net mass balances. The mean winter balance shows less accumulation at low elevations $\left(0.3 \mathrm{mw}_{\text {e.e }} \mathrm{yr}^{-1}\right.$ ) than at higher elevations (above $1.4 \mathrm{mw}$.e. $\mathrm{yr}^{-1}$ ) (Fig. 3a), with a mean orographic gradient of about $0.2 \mathrm{mw}$.e. $\mathrm{yr}^{-1}$ per $100 \mathrm{~m}$ increase in elevation. Figure $3 \mathrm{a}$ illustrates the spatial distribution of the annual change in winter balance, showing 15 that the terminus, the marginal areas at high elevations, and areas near mountain ridges had the smallest decrease, and in some areas an increasing winter balance $\left(0.04 \mathrm{mw}\right.$.e. $\left.\mathrm{yr}^{-2}\right)$. The largest decreases $\left(-0.20 \mathrm{mw}\right.$.e. $\left.\mathrm{yr}^{-2}\right)$ occurred at the center line of the glacier and at higher elevations, most pronounced at about $500 \mathrm{~m}$ a.s.l. Meteorological observations at MG show that the mean winter (September through May) wind speed has increased (insignificantly) in recent years (Mernild et al., 2008c). Also, katabatic winds from the north and east (dominating around $50 \%$ of the time) were stronger at the center of MG than near the margins. The inhomogeneous annual change in winter accumulation can therefore most likely be linked to increasing wind speed and snow redistribution (Hasholt et al., 2003). Snow usually begins to drift at a wind speed above $255.0 \mathrm{~ms}^{-1}$ ( $2 \mathrm{~m}$ above surface) influenced by e.g. snow age, temperature, grain size

Thinning and slowdown of Greenland's Mittivakkat Gletscher

S. H. Mernild et al.

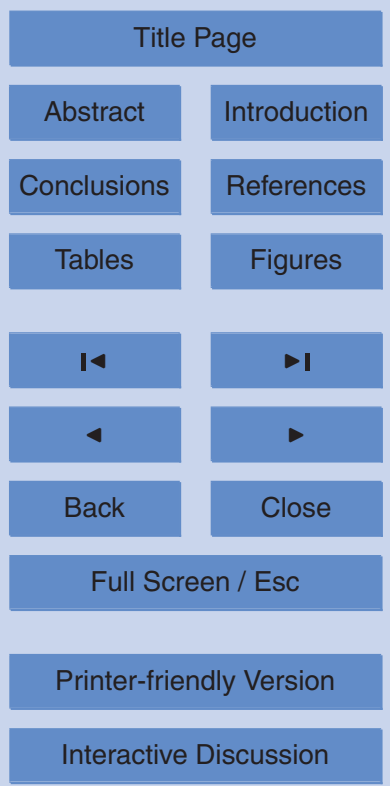


(Liston and Sturm, 1998). For MG the mean winter speed for snow drifting was exceeded $29 \%$ of the time, with an increase (insignificant) in recent years (Mernild et al., 2008c).

The summer balance shows more ablation at low elevations and decreasing mass 5 loss towards higher elevations (Fig. 3b), as expected. The summer mass balance varied from -3.6 mw.e. $\mathrm{yr}^{-1}$ at low elevations to $-1.4 \mathrm{mw}$.e. $\mathrm{yr}^{-1}$ at high elevations, giving a mean gradient of $0.3 \mathrm{mw}^{-e} . \mathrm{yr}^{-1}$ per $100 \mathrm{~m}$ increase in elevation. Figure $3 \mathrm{~b}$ illustrates the spatial distribution of the annual change in summer balance, showing the largest change towards the margins, most pronounced in the southern part of the 10 glacier $\left(-0.22 \mathrm{mw}\right.$.e. $\left.\mathrm{yr}^{-2}\right)$. A possible explanation for this pattern is that as the margins receded, the surface albedo reduces e.g. due to eolian and englacially transported debris exposed at the ice surface and the increasing convection of heat from the surrounding areas, causing more melting, whereas towards the center of the glacier the energy balance is less affected (Fig. 3b).

15 The net mass balance shows the combined effects of changes in winter and summer balances. The net mass balance shows the greatest net ablation at low elevations $\left(-3.0 \mathrm{mw}\right.$.e. $\left.\mathrm{yr}^{-1}\right)$ and lowest values at higher elevations $\left(0.4 \mathrm{mw}\right.$.e. $\left.\mathrm{yr}^{-1}\right)$ (Fig. 3c). The mean net mass balance gradient was $0.5 \mathrm{mw}$.e. $\mathrm{yr}^{-1}$ per $100 \mathrm{~m}$. The annual change in net mass balance is inhomogeneous, with the largest changes in the marginal area in the south $\left(-0.24 \mathrm{mw}\right.$.e. $\left.\mathrm{yr}^{-2}\right)$ and at the center line (around $-0.16 \mathrm{mw} . e . \mathrm{yr}^{-2}$ ). The increasing mass loss at $\sim 500 \mathrm{~m}$ a.s.l. probably reflects that in this area, more ice has been exposed in recent years compared with previous periods when mainly snow and firn were exposed at the surface. Due to this change in surface exposure, a change in surface albedo has occurred from $0.8-0.9$ for snow to around 0.4 for bare ice, highly reinforcing the surface melt of $M G$, especially at mid to high elevations.

Surface elevation and thickness decreased across the glacier from 1995-2011 (Fig. 5a, b). Surface elevation changes ( $\mathrm{d} h / \mathrm{d} t$ calculated from Eq. 2) for the longitudinal MG profile are -6 to $-38 \mathrm{~m}$ w.e. (averaging $-23 \mathrm{~m}$ w.e.) on the lower part of the glacier at stakes $31,40,50,60$, and 70 , and -2 to $-3 \mathrm{~m}$ w.e. (averaging $-2 \mathrm{~m}$ w.e.) on the

\section{Thinning and slowdown of Greenland's Mittivakkat Gletscher}

S. H. Mernild et al.

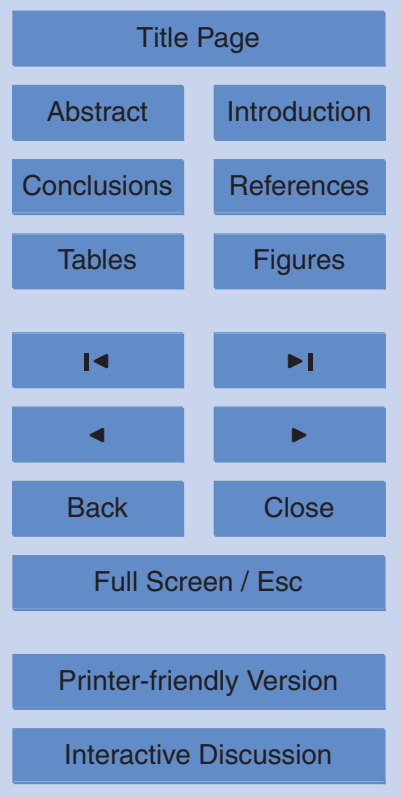


upper part at stakes 110,120,130, and 140 (Fig. 5b, green line). The surface elevation change due to SMB alone was more negative than the total elevation changes: -25 to $-44 \mathrm{~m}$ w.e. (averaging $-37 \mathrm{~m}$ w.e.) in the lower part and -6 to $-12 \mathrm{~m}$ w.e. (averaging $-8 \mathrm{~m}$ w.e.) in the upper part (Fig. $5 \mathrm{~b}$, red line). Vertical strain was able to compensate 5 for about $60 \%$ of the elevation change due to SMB in the lower part, and about $25 \%$ in the upper part, and overall on average about $50 \%$ for the longitudinal profile. The vertical strain was unevenly distributed along the longitudinal profile (Fig. 5b, blue line), with the greatest compensation at central elevations at stake $80\left(w_{\mathrm{e}}=20 \mathrm{~m}\right)$ where the mean surface velocity was greatest, and decreasing towards high and low elevations.

\subsection{Volume changes}

The glacier-covered area is one of the easiest glacier morphometric quantities to measure (e.g. Bahr, 2011). For MG, the surface area was estimated for the years 1986, 1999 , and 2011 based on satellite imagery, where the area decreased by $18 \%$ during this period (Mernild et al., 2012). For the same period, the estimated mean ice thickness was reduced by $15 \%$, from $115 \pm 17 \mathrm{~m}$ (1986) to $110 \pm 17 \mathrm{~m}$ (1999) to $97 \pm 15 \mathrm{~m}$ (2011) (where the uncertainties are assumed equal to the methodic mass balance uncertainly of $\pm 15 \%$ ). Based on observed changes in area cover and mean thickness, the mean volume diminished by $1.10 \mathrm{~km}^{3}$ (30\%) (Fig. 4), from $3.65 \pm 0.54 \mathrm{~km}^{3}$ (1986) to $3.25 \pm 0.50 \mathrm{~km}^{3}$ (1999) to $2.55 \pm 0.39 \mathrm{~km}^{3}$ (2011). This volume decrease occurred con20 temporaneous with a highly significant observed increase in mean annual air temperature (MAAT) and decrease in mean annual (uncorrected) precipitation of $0.09^{\circ} \mathrm{Cyr}^{-1}$ $\left(r^{2}=0.51 ; p<0.01\right)$ and $-8 \mathrm{~mm}$ w.e. $\mathrm{yr}^{-2}\left(r^{2}=0.08 ; p<0.10\right)(1986-2011)$, respectively, at the nearby DMI Station in Tasiilaq (DMI, 2011). Climate records from other meteorological stations in Southeast Greenland show significant warming since the early 1980s, suggesting that the MG trends are not merely a local phenomenon, but indicative of glacier changes in the broader region (Mernild et al., 2011a).

\section{TCD}

$6,4387-4415,2012$

Thinning and slowdown of Greenland's Mittivakkat Gletscher

S. H. Mernild et al.

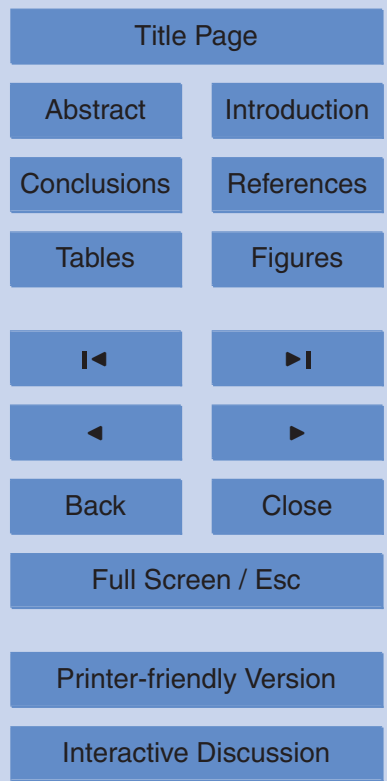




\subsection{Surface velocity changes}

The surface velocity of MG has been observed since 1996/1997 at stake locations (Fig. 1). The spatial distribution of the mean surface velocity has a maximum of $22 \mathrm{myr}^{-1}$ near the center of the glacier (shown by red color in Fig. 6a). The velocity 5 decreases to $\sim 3-5 \mathrm{myr}^{-1}$ at the lateral margins as a result of drag from the valley walls and low ice thickness (e.g. Cuffey and Paterson, 2010). The highest surface velocities are observed where the ice is thickest, and at the two cirques to the south of MG. In this context it has to be emphasized that the estimation of the spatial surface velocity field is likely to have higher degree of uncertainty towards the crevassed parts of the glacier where no data is available.

Over the 15-yr period (1996/1997-2010/2011), surface velocity has decelerated across the glacier, with over $50 \%$ in much of the ablation zone. However, the change in annual surface velocity has been unevenly distributed across the glacier (Fig. 6b). The greatest deceleration, about $0.6 \mathrm{~m} \mathrm{yr}^{-2}$, is observed on the lower part of the glacier near the margins (Fig. 6b), where the greatest mass loss has also occurred (Fig. 3c).

The decelerating change in annual surface velocity observed across MG is likely related to the decrease in thickness over the glacier, which will decrease both deformation and sliding velocity (Cuffey and Paterson, 2010). An alternative explanation for the slowing velocity is that changes in subglacial hydrology from increased surface melting over the study period have led to an earlier and more extensive development of channelized drainage and subsequent decrease in sliding each summer (Schoof, 2010; Sundal et al., 2011).

To assess how much of the deceleration in surface velocity that can be explained by changes in thickness, we calculate the theoretical surface velocity due to deformation at the beginning and end of the study period using the shallow ice approximation (Hutter, 1983) as:

$v_{\text {sia }}=1 / 2 A(\rho g \mathrm{~d} S / \mathrm{d} x)^{3} H^{4}$

Thinning and slowdown of Greenland's Mittivakkat Gletscher

S. H. Mernild et al.

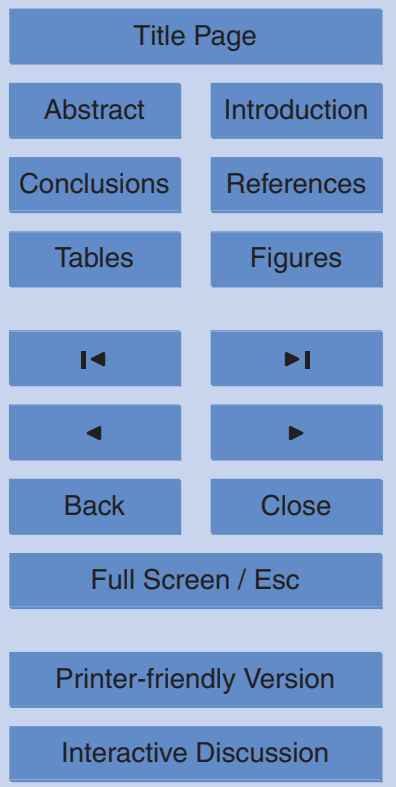


where $A$ is the flow law rate factor, taken as $2.1 \times 10^{-16} \mathrm{yr}^{-1} \mathrm{~Pa}^{-3}$ for isothermal ice at $0^{\circ} \mathrm{C}$ (Cuffey and Paterson, 2010), $\rho$ is the density of ice, taken as $900 \mathrm{~kg} \mathrm{~m}^{-3}, g$ is acceleration due to gravity, $9.81 \mathrm{~m} \mathrm{~s}^{-2}, \mathrm{~d} S / \mathrm{d} x$ is the surface slope, and $H$ is the ice thickness. We apply Eq. (4) within the ablation area along the longitudinal profile in

5 Fig. 7, running the calculation midway between stake locations, based on the values of thickness, slope, and observed velocity averaged between the two adjacent stake locations. This provides a flowline average over 3-5 ice thicknesses, which compensates somewhat for the fact that the shallow ice approximation ignores longitudinal and lateral stresses that may be important for a mountain glacier. A shape factor is not used because MG is wide relative to its depth (half-width/thickness $=\sim 10$ ).

Though the calculation of $v_{\text {sia }}$ has a high degree of uncertainty due to uncertainty in the flow rate factor and the lack of higher order stresses, the calculations indicate that the observed changes in surface velocity can largely be explained by the thickness changes over the study period (Fig. 7). Our calculation of $v_{\text {sia }}$ does not include 15 a contribution to surface velocity from sliding, which is typically a large component on temperate glaciers (Weertman, 1957; Cuffey and Paterson, 2010). However, sliding velocity is commonly assumed to vary with ice thickness to a power that ranges from one to three (Bindschadler, 1983; Clarke, 2005; Cuffey and Paterson, 2010), and allowing a component of surface velocity due to sliding (e.g. by lowering $A$ ) with powers that 20 range from one to three, we find that the change in thickness can still explain most of the change in observed velocity without requiring changes in sliding related to hydrology since thickness changes affect sliding in a similar fashion as deformation.

The alternative hypothesis is that the observed surface velocity is due to a reduction in basal sliding associated with changing hydrology. Though meltwater draining to the 25 beds of glaciers can increase sliding initially, once subglacial hydrologic systems adjust to the input, sliding can decrease with sustained meltwater input (Bartholomaus et al., 2008; Schoof, 2010) potentially leading to lower average summer velocity (Truffer et al., 2005; Vincent et al., 2009; Sundal et al., 2011). Summer mass balance (and by association, melt) has become increasingly negative across MG during the study

\section{Thinning and slowdown of Greenland's Mittivakkat Gletscher}

S. H. Mernild et al.

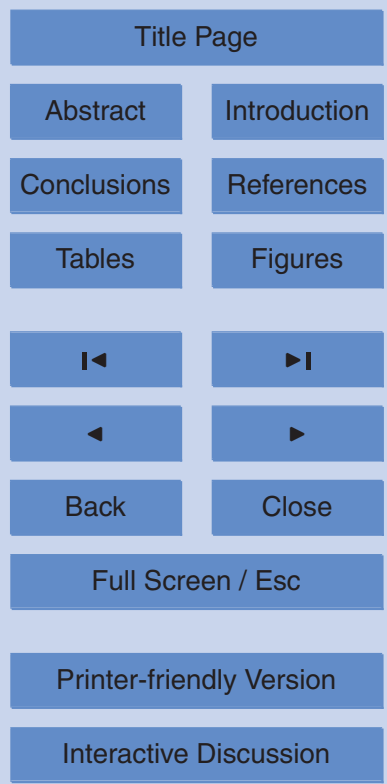

Interactive Discussion 
period (Fig. 3b). However, changes in melt appear to have only a minor impact on surface velocity at the seasonal scale. Summer mass balance and mean June-July-August (JJA) temperatures, both proxies for melt, have weak negative correlation with mean annual surface velocity $\left(r^{2}=0.15\right.$, insignificant at $p<0.25$, and $r^{2}=0.30$, significant 5 at $p<0.025$, respectively), while thickness is positively correlated with surface velocity $\left(r^{2}=0.64\right.$, significant at $p<0.01$, Fig. 8). Thus changes to summer melt are not important for changes in velocity relative to the change in thickness that occurred.

Based on these analyses, we conclude that the observed $15 \mathrm{yr}$ slowdown is due to decreasing ice deformation (and possibly sliding) resulting from glacier thinning, and o changes to hydrology during that time do not seem to be important. This is consistent with previous studies that found time periods of decadal lengths necessary to observe the dynamic effects of thinning. Vincent et al. (2009) recorded $20 \mathrm{yr}$ of thickening and speedup followed by $30 \mathrm{yr}$ of thinning and slowdown at Glacier d'Argentière, France. Müller and Iken (1973) found small $(\sim 1 \mathrm{~m})$ thickness changes inadequate to explain 15 annual velocity changes over a 2-3 yr period on White Glacier, Arctic Canada.

\subsection{Seasonal velocity variations}

On a seasonal scale, the daily MG surface velocity was observed during two periods (May 2004 through July 2005, and March 2009 through August 2010) (Fig. 9a) (see Fig. 1 for locations of the GPS stations). For the summer (June through August) the 20 mean ice surface velocity varied between 0.061 and $0.066 \mathrm{~m} \mathrm{~d}^{-1}$, with a maximum observed daily velocity of $0.10 \mathrm{md}^{-1}$ (26 June 2005). For the winter (September through May) the velocity varied between 0.038 and $0.043 \mathrm{md}^{-1}$. The summer values are 50$60 \%$ higher than the winter background values, and up to $160 \%$ higher for peak events (Fig. 9a, b). Similar seasonal patterns in ice surface velocity were observed at the Flade 25 Isblink ice cap (the largest ice cap in Greenland), Northeast Greenland (Palmer et al., 2010), at the John Evans Glacier, Nunavut, Canada (Bingham et al., 2003), and at the western land-terminating margin of the GrIS, where the peak summer velocity was up to $220 \%$ above the winter background velocity (Bartholomew et al., 2010; Hoffman

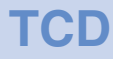

6, 4387-4415, 2012

Thinning and slowdown of Greenland's Mittivakkat Gletscher

S. H. Mernild et al.

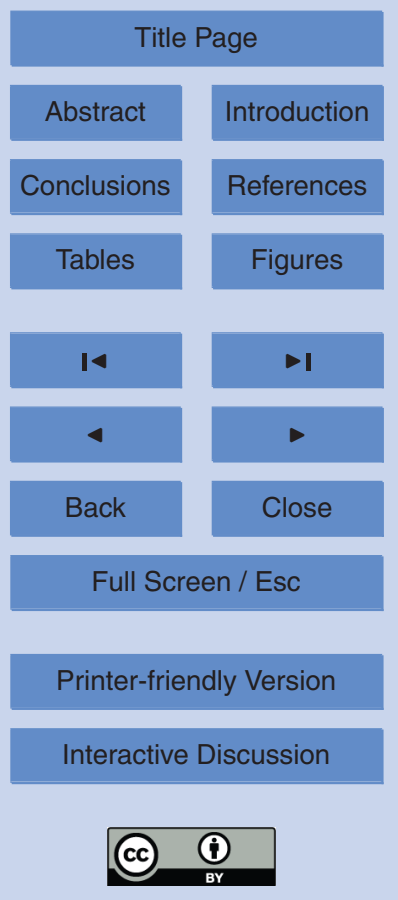


et al., 2011). There is some evidence that increases in water storage are associated with increases in sliding. MG peak velocity events were typically accompanied by uplift of a few centimeters. Similar uplift has been observed for mountain glaciers (e.g. Iken et al., 1983; Bartholomaus et al., 2008; Howat et al., 2008) and the GrIS (e.g. 5 Bartholomew et al., 2010; Hoffman et al., 2011; Sole et al., 2011) during speedup events.

The seasonal pattern in the daily surface velocity demonstrates the spring speedup, which is common on temperate mountain glaciers (e.g. Iken et al., 1983; Nienow et al., 1998; Anderson et al., 2004). At the beginning of each summer, velocity increase fol10 lows increasing air temperature, peaking in early to mid June. After this initial speedup, velocity has little clear relationship with air temperature until the end of summer when air temperatures fall to and remain well below freezing (Fig. 9). This behavior is consistent with transient speedup when subglacial water storage is increasing in spring and water inputs encounter an undeveloped drainage system (e.g. Truffer et al., 2005; 15 Bartholomaus et al., 2008). As pressurization of the distributed system and melting of basal ice by water flow creates efficient subglacial channels, increasing inputs of water are required to overwhelm the capacity of the hydrologic system and sustain sliding, and if water inputs are inadequate, sliding decreases (Bartholomaus et al., 2008; Schoof, 2010). After the development of efficient channels, they will close by creep once water pressure becomes low, but for the thin ice of MG $(\sim 100 \mathrm{~m})$ the time scale for channel closure is weeks (Nye, 1953; Bartholomaus et al., 2008), meaning successive melt events may be unable to pressurize the system and maintain sliding. 25 July to 5 August 2004, 30 June to 19 July 2009, and 13 June to 18 July 2010 are examples of multi-week periods of increasing high temperatures during mid-summer accompanied by a slowdown in surface velocity (Fig. 9a). Despite these complex variations in sliding during summer, changes to hydrology over the $15 \mathrm{yr}$ study period do not appear to be the primary cause of the observed long-term deceleration (Sect. 4.3).

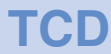

$6,4387-4415,2012$

Thinning and slowdown of Greenland's Mittivakkat Gletscher

S. H. Mernild et al.

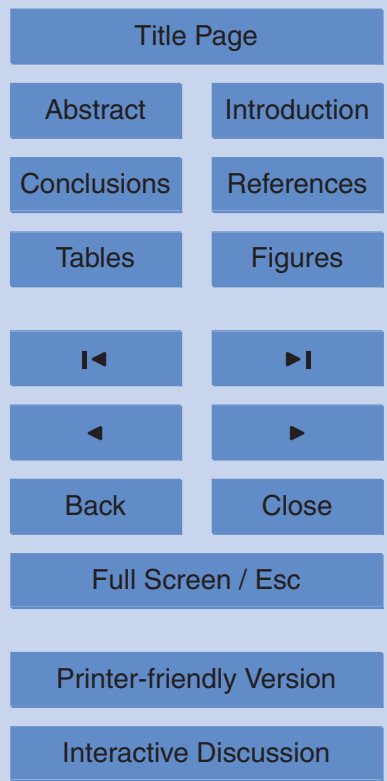




\section{Conclusions}

Direct mass balance observations from Greenland's independent glaciers (glaciers disconnected to the GrIS) are rare, and MG is the glacier in Greenland with the longest mass balance observation time series. We have analyzed spatially distributed winter, 5 summer, and annual mass balances and ice surface velocities based on direct observations of the MG, along with calculated mean ice thickness and volume changes. We have found unambiguous evidence of ice thinning and slowdown in a warming climate. From 1986-2011 we found significant decreases in mean ice thickness (15\%), ice volume $(30 \%)$, and mean annual surface velocity $(30 \%)$. The decrease in surface 10 velocity was likely a dynamic effect of ice thinning. Observations of MG, as presented here, will be crucial for understanding the behavior of Greenland's peripheral glaciers in a warming climate.

Acknowledgements. We extend a very special thanks to Mauri Pelto and the anonymous reviewer for their insightful critique of this article. This work was partly supported by the Climate Change Prediction Program and by the Scientific Discovery for Advanced Computing (SciDAC) program within the US Department of Energy's Office of Science and by a Los Alamos National Laboratory (LANL) Director's Fellowship. LANL is operated under the auspices of the National Nuclear Security Administration of the US Department of Energy under Contract No. DE-AC52-06NA25396), and partly from the European Community's Seventh Framework Programme under grant agreement No. 262693. Thanks are given to the Geological Survey of Denmark and Greenland (GEUS) for providing GPS-based surface velocity time series from the Mittivakkat Gletscher, to the University of Copenhagen for providing meteorological data from the Mittivakkat Gletscher (Station Nunatak), and to the Danish Meteorological Institute for providing WMO synoptic meteorological data from Tasiliaq. NTK, SHM, and JCY did the

25 MG mass balance observations. SHM and NTK planned and analyzed the data, and SHM, NTK, MJH, and JCY wrote the manuscript, and WHL, EH, RSF, and JKM contributed to the discussion of results and writing of the text.

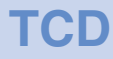

$6,4387-4415,2012$

Thinning and slowdown of

Greenland's Mittivakkat Gletscher

S. H. Mernild et al.

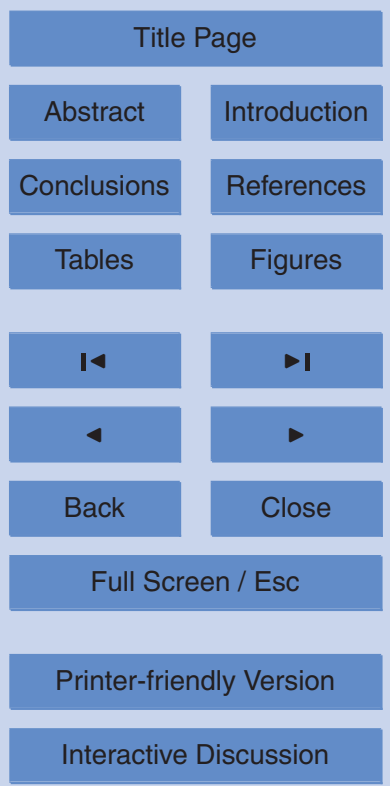




\section{References}

Anderson, R. S., Anderson, S. P., MacGregor, K. R., Waddington, E. D., O'Neel, S., Riihimaki, C. A., and Loso, M. G.: Strong feedbacks between hydrology and sliding of a small alpine glacier, J. Geophys. Res., 109, 1-17, 2004.

5 Bahr, D. B.: Estimation of glacier volume and volume change by scaling methods, in: Encyclopedia of Snow, Ice, and Glaciers, edited by: Singh, V. P., Singh, P., and Haritashya, U. K., Springer, Dordrecht, The Netherlands, 1253 pp., 278-280, 2011.

Bartholomaus, T. C., Andersen, R. S., and Andresen, S. P.: Response of glacier basal motion to transient water storage, Nat. Geosci., 1, 33-37, doi:10.1038/ngeo.2007.52, 2008.

Bartholomew, I., Nienow, P., Mair, D., Hubbard, A., King, M., and Sole, A.: Seasonal evolution of subglacial drainage and acceleration in a Greenland outlet glacier, Nat. Geosci., 3, 408-411, 2010.

Bindschadler, R.: The importance of pressurized subglacial water in separation and sliding at the glacier bed, J. Glaciol., 29, 3-19, 1983.

15 Bingham, R. G., Nienow, P., and Sharp, M. J.: Intra-annual and intra-seasonal flow dynamics of a high Arctic polythermal valley glacier, Ann. Glaciol., 37, 181-188, 2003.

Clarke, G. K. C.: Subglacial processes, Annu. Rev. Earth PI. Sc., 33, 247-276, 2005.

Cogley, G.: The future of the world's glaciers, in: The Future of the World's Climate, doi:10.1016/B978-0-12386917-3.00008-7, 197-222, 2012.

20 Cogley, J. G. and Adams, W. P.: Mass balance of glaciers other than the ice sheet, J. Glaciol., 44, 315-325, 1998.

Cuffey, K. M. and Paterson, W. S. B.: The Physics of Glaciers, 4th edn., Elsevier, Oxford, UK, 707 pp., 2010.

DMI: Weather and Climate Data from Greenland 1958-2010 - Descriptions and Documentation of Observations of Temperature, Precipitation, Wind, Cloud Cover, Air Pressure, Humidity and Depth of Snow, Technical Report, Elsevire, Amsterdam, The Nederlands, 11-10, 2011.

Hanna, E., Huybrechts, P., Steffen, K., Cappelen, J., Huff, R., Shuman, C., Irvine-Fynn, T., Wise, S., and Griffiths, M.: Increased runoff from melt from the Greenland Ice Sheet: a response to global warming, J. Climate, 21, 331-341, doi:10.1175/2007JCLI1964.1, 2008.

Hanna, E., Jones, J. M., Cappelen, J., Mernild, S. H., Wood, L., Steffen, K., and Huybrechts, P.: The influence of North Atlantic atmospheric and oceanic forcing effects on 1900-2010 Greenland summer climate and ice melt/runoff, Int. J. Climatol., doi:10.1002/joc.3475, 2012.

\section{Thinning and slowdown of Greenland's Mittivakkat Gletscher}

S. H. Mernild et al.

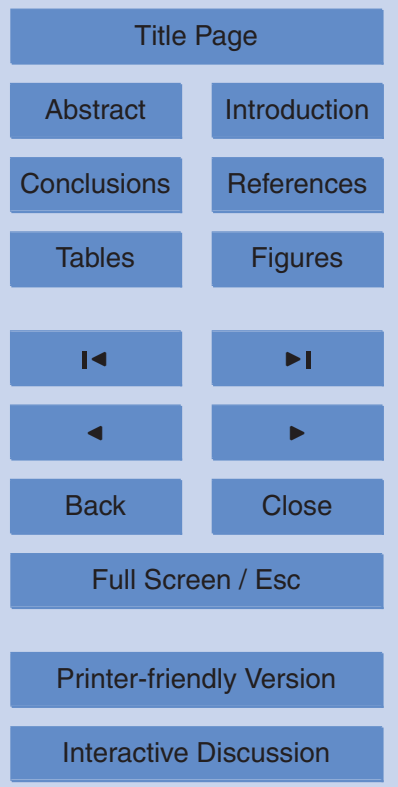


Hasholt, B., Liston, G. E., and Knudsen, N. T.: Snow-distribution modelling in the Ammassalik Region, South East Greenland, Nord. Hydrol., 34, 1-16, 2003.

Hoffman, M. J., Catania, G. A., Neumann, T. A., Andrews, L. C., and Rumrill, J. A.: Links between acceleration, melting, and supraglacial lake drainage of the Western Greenland Ice

$5 \quad$ Sheet, J. Geophys. Res., 116, F04035, doi:10.1029/2010JF001934, 2011.

Howat, I. M., Tulaczyk, S., Waddington, E., and Björnsson, H.: Dynamic controls on glacier basal motion inferred from surface ice motion, J. Geophys. Res., 113, 1-15, 2008.

Hutter, K.: Theoretical Glaciology: Material Science of Ice and the Mechanics of Glaciers and Ice Sheets, Dordrecht, Springer, 510 pp., 1983.

10 Iken, A., Röthlisberger, H., Flotron, A., and Haeberli, W.: The uplift of Unteraargletscher at the beginning of the melt season - a consequence of water storage at the bed?, J. Glaciol., 29, 28-47, 1983.

Jacob, T., Wahr, J., Pfeffer, W. T., and Swenson, S.: Recent contributions of glaciers and ice caps to sea level rise, Nature, 482, 514-518, doi:10.1038/nature10847, 2012.

Kamb, B. and LaChapelle, E.: Direct observations of the mechanism of glacier sliding over bedrock, J. Glaciol., 5, 159-172, 1964.

Kargel, J. S., Ahlstrøm, A. P., Alley, R. B., Bamber, J. L., Benham, T. J., Box, J. E., Chen, C., Christoffersen, P., Citterio, M., Cogley, J. G., Jiskoot, H., Leonard, G. J., Morin, P., Scambos, T., Sheldon, T., and Willis, I.: Brief communication: Greenland's shrinking ice cover: "fast times" but not that fast, The Cryosphere, 6, 533-537, doi:10.5194/tc-6-533-2012, 2012.

Kaser, G., Cogley, J. C., Dyurgerov, M. B., Meier, M. F., and Ohmura, A.: Mass balance of glaciers and ice caps: consensus estimates for 1961-2004, Geophys. Res. Lett., 33, 1-5, 2006.

Knudsen, N. T. and Hasholt, B.: Radio-echo sounding at the Mittivakkat Gletscher, Southeast Greenland, Arct. Antarct. Alp. Res., 31, 321-328, 1999.

Knudsen, N. T. and Hasholt, B.: Mass balance observations at Mittivakkat Glacier, Southeast Greenland 1995-2002, Nord. Hydrol., 35, 381-390, 2004.

Knudsen, N. T., Nørnberg, P., Yde, J. C., Hasholt, B., and Heinemeier, J.: Recent marginal changes of the Mittivakkat Glacier, Southeast Greenland and the discovery of remains of reindeer (Rangifer tarandus), polar bear (Ursus maritimus) and peaty material, Danish J. Geogr., 108, 137-142, 2008.

Leclercq, P. W. and Oerlemans, J.: Global and hemispheric temperature reconstruction from glacier length fluctuations, Clim. Dynam., 38, 1065-1079, 2012.

\section{Thinning and slowdown of Greenland's Mittivakkat Gletscher}

S. H. Mernild et al.

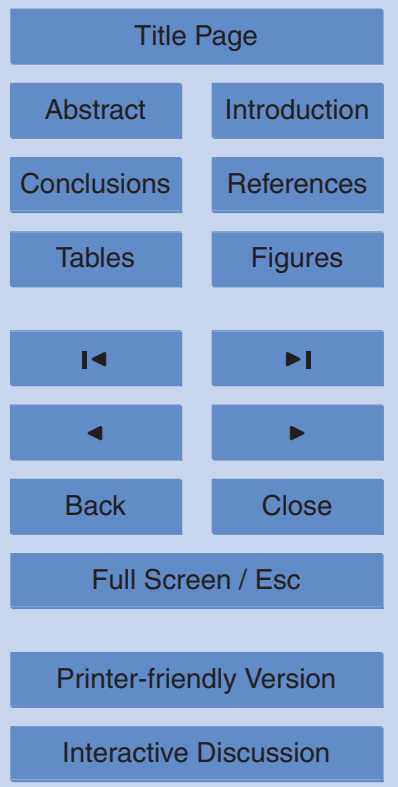


Liston, G. E. and Sturm, M.: A snow-transport model for complex terrain, J. Glaciol., 44, 498516, 1998.

Meier, M. F., Dyurgerov, M. B., Rick, U. K., O'Neel, S., Pfeffer, W. T., Anderson, R. S., Anderson, S. P., and Glazovsky, A. F.: Glaciers dominate eustatic sea-level rise in the 21st century, $5 \quad$ Science, 317, 1064-1067, 2007.

Mernild, S. H. and Hasholt, B.: Climatic control on river discharge simulations, Mittivakkat Glacier catchment, Ammassalik Island, SE Greenland, Nord. Hydrol., 37, 327-346, 2006.

Mernild, S. H. and Hasholt, B.: Observed runoff, jökulhlaups, and suspended sediment load from the Greenland Ice Sheet at Kangerlussuaq, West Greenland, for 2007 and 2008, J.

10 Glaciol., 55, 855-858, 2009.

Mernild, S. H. and Liston, G. E.: Greenland freshwater runoff. Part II: Distribution and trends, 1960-2010, spatial runoff distribution and trends from Greenland to adjacent seas, 19602010, J. Climate, 25, 6015-6035, 2012.

Mernild, S. H., Liston, G. E., Hasholt, B., and Knudsen, N. T.: Snow distribution and melt model15 ing for Mittivakkat Glacier, Ammassalik Island, SE Greenland, J. Hydrometeorol., 7, 808-824, 2006.

Mernild, S. H., Liston, G. E., Kane, D. L., Hasholt, B., and Knudsen, N. T.: Spatial snow distribution, runoff, and mass balance modelling for entire Mittivakkat Glacier (1998-2006), Ammassalik Island, SE Greenland, Danish J. Geogr., 108, 121-136, 2008a.

20 Mernild, S. H., Kane, D. L., Hansen, B. U., Jakobsen, B. H., Hasholt, B., and Knudsen, N. T.: Climate, glacier mass balance, and runoff (1993-2005) for the Mittivakkat Glacier catchment, Ammassalik Island, SE Greenland, and in a long term perspective (1898-1993), Hydrol. Res., 39, 239-256, 2008b.

Mernild, S. H., Hansen, B. U., Jakobsen, B. H., and Hasholt, B.: Climatic conditions at the Mittivakkat Glacier catchment (1994-2006), Ammassalik Island, SE Greenland, and in a 109 years term perspective (1898-2006), Danish J. Geogr., 108, 51-72, 2008c.

Mernild, S. H., Liston, G. E., Steffen, K., van den Broeke, M., and Hasholt, B.: Runoff and massbalance simulations from the Greenland Ice Sheet at Kangerlussuaq (Søndre Strømfjord) in a 30-year perspective, 1979-2008, The Cryosphere, 4, 231-242, doi:10.5194/tc-4-231-2010, $30 \quad 2010$

Mernild, S. H., Knudsen, N. T., Lipscomb, W. H., Yde, J. C., Malmros, J. K., Hasholt, B., and Jakobsen, B. H.: Increasing mass loss from Greenland's Mittivakkat Gletscher, The Cryosphere, 5, 341-348, doi:10.5194/tc-5-341-2011, 2011a.

Thinning and slowdown of Greenland's Mittivakkat Gletscher

S. H. Mernild et al.

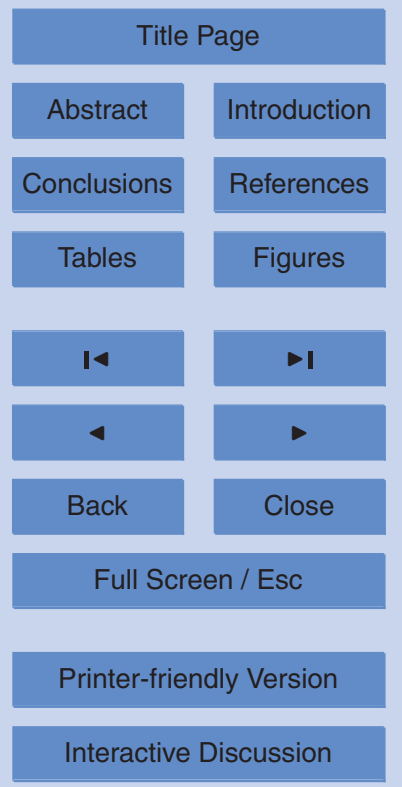


Mernild, S. H., Knudsen, N. T., and Hanna, E.: Mittivakkat Gletscher, SE Greenland, in: The Arctic Report Card, Greenland, edited by: Richter-Menge, J., Jeffries, M. O., Overland, J. E., NOAA Report 2011, 2011b.

Mernild, S. H., Malmros, J. K., Yde, J. C., and Knudsen, N. T.: Multi-decadal marine- and 5 land-terminating glacier recession in the Ammassalik region, southeast Greenland, The Cryosphere, 6, 625-639, doi:10.5194/tc-6-625-2012, 2012.

Müller, F. and Iken, A.: Velocity Auctuations and water regime of Arctic valley glaciers, Union Geiodeìsique et Geìophysique Internationale, Association Internationale d'Hydrologie Scientifique, Commission de Neiges et Glaces, Symposium on the Hydrology of Glaciers, Cam10 bridge, 7-13 September 1969, 165-182, 1973.

Nienow, P., Sharp, M., and Willis, I.: Seasonal changes in the morphology of the subglacial drainage system, Haut Glacier d'Arolla, Switzerland, Earth Surf. Proc. Landforms, 23, 825843, 1998.

Nye, J. F.: The flow law of ice from measurements in glacier tunnels, laboratory experiments and the Jungfraufirn borehole experiment, Proc. R. Soc. A, 219, 477-489, 1953.

Oerlemans, J., Dyurgerov, M., and van de Wal, R. S. W.: Reconstructing the glacier contribution to sea-level rise back to 1850, The Cryosphere, 1, 59-65, doi:10.5194/tc-1-59-2007, 2007.

Østrem, G. and Brugman, M.: Glacier mass balance measurements, a manual for field and office work, NRHI Science Report, Environmental Canada, No. 4, 224 pp., 1991.

20 Palmer, S. J., Shepherd, A., Sundal, A., Rinne, E., and Nienow, P. W.: InSAR observations of ice elevation and velocity fluctuations at the Flade Isblink ice cap, Eastern North Greenland, J. Geophys. Res., 115, F04037, doi:10.1029/2010JF001686, 2010.

Rastner, P., Bolch, T., Mölg, N., Machguth, H., and Paul, F.: The first complete glacier inventory for the whole of Greenland, The Cryosphere Discuss., 6, 2399-2436, doi:10.5194/tcd-62399-2012, 2012.

Schoof, C.: Ice sheet acceleration driven by melt supply variability, Nature, 468, 803-806, doi:10.1038/nature09618, 2010.

Sole, A. J., Mair, D. W. F., Nienow, P. W., Bartholomew, I. D., King, M. A., Burke, M. J., and Joughin, I.: Seasonal speedup of a Greenland marine-terminating outlet glacier forced 30 by surface melt-induced changes in subglacial hydrology, J. Geophys. Res., 116, F03014, doi:10.1029/2010JF001948, 2011.

\section{Thinning and slowdown of Greenland's Mittivakkat Gletscher}

S. H. Mernild et al.

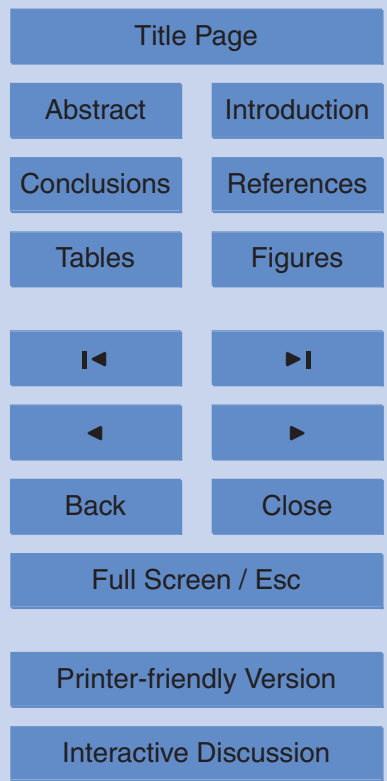


Sundal, A. V., Shepherd, A., Nienow, P. W., Hanna, E., Palmer, S., and Huybrechts, P.: Melt induced speed-up of Greenland ice sheet offset by efficient subglacial drainage, Nature, 469, 521-524, doi:10.1038/nature09740, 2011.

Truffer, M., Harrison, W. D., and March, R. S.: Correspondance, J. Glaciol., 51, 663-664, 2005.

5 van der Wal, R. S. W., Boot, W., van den Broeke, M., Smeets, C. J. P. P., Reijmer, C. H., Donker, J. J. A., and Oerlemans, J.: large and rapid melt-induced velocity changes in the ablation zone of the Greenland Ice Sheet, Science, 321, 111-113, 2008.

Vincent, C., Soruco, A., Six, D., and Le Meur, E.: Glacier thickening and decay analysis from 50 years of glaciological observations performed on Glacier d'Argentieire, Mont Blanc area, 10 France Ann. Glaciol., 50, 73-79, 2009.

Weertman, J.: On the sliding of glaciers, J. Glaciol., 3, 33-38, 1957.

Yde, J. C. and Knudsen, N. T.: 20th-century glacier fluctuation on Disko Island (Qeqertarsuaq), Greenland, Ann. Glaciol., 46, 209-214, 2007.

\section{Thinning and slowdown of Greenland's Mittivakkat Gletscher}

S. H. Mernild et al.

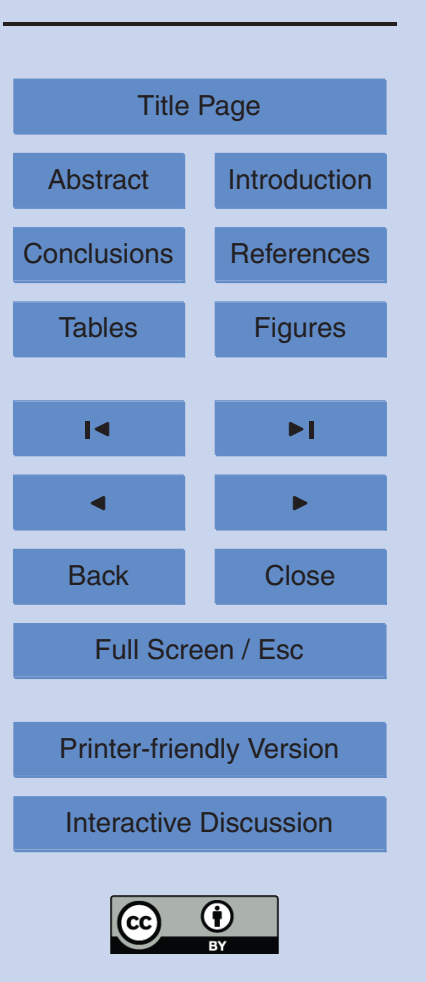




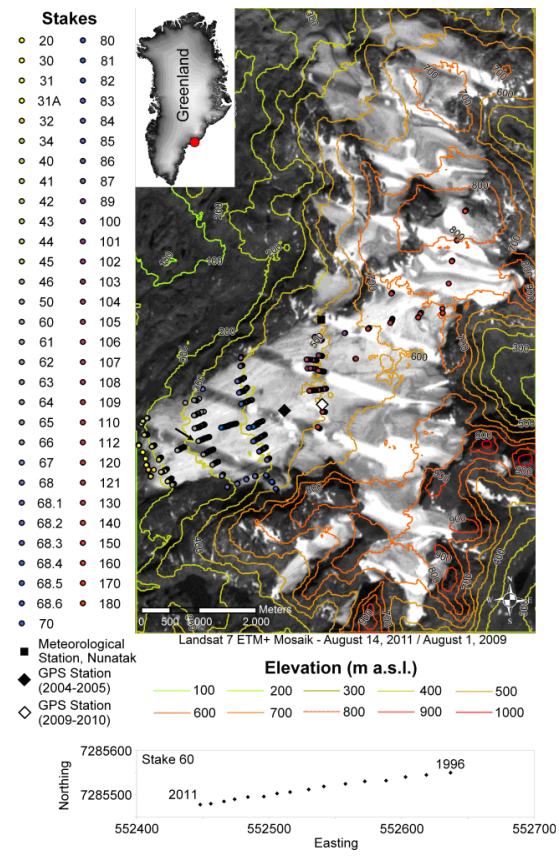

Fig. 1. The Mittivakkat Gletscher $\left(26.2 \mathrm{~km}^{2}\right.$, where the measured mass-balance area is $17.6 \mathrm{~km}^{2} ; 65^{\circ} 41^{\prime} \mathrm{N}, 37^{\circ} 48^{\prime} \mathrm{W}$ ) including topographic map (100-m contour interval), and circles illustrating the stake locations for the glacier observation program, 1995 through 2011. The stake colors on the glacier surface correspond to the stake numbers illustrated to the left, where the low numbers corresponds to the stakes at the low elevation part of the glacier, and vice versa. Due to a high density of crevasses in the SE part of the glacier, no stakes were located there. The meteorological station at the nunatak is shown by a black square and the GPS station on the glacier by black and white diamonds. The inset figure indicates the location of the Mittivakkat Gletscher in Southeastern Greenland. Below, an example of an annual time series (1996-2011) of stake locations is shown for stake 60, denoted by a black arrow on the map (source: Landsat 7 ETM+ Mosaic, 14 August, 1 August 2011, 2009).

\section{TCD}

6, 4387-4415, 2012

\section{Thinning and slowdown of Greenland's Mittivakkat Gletscher}

S. H. Mernild et al.

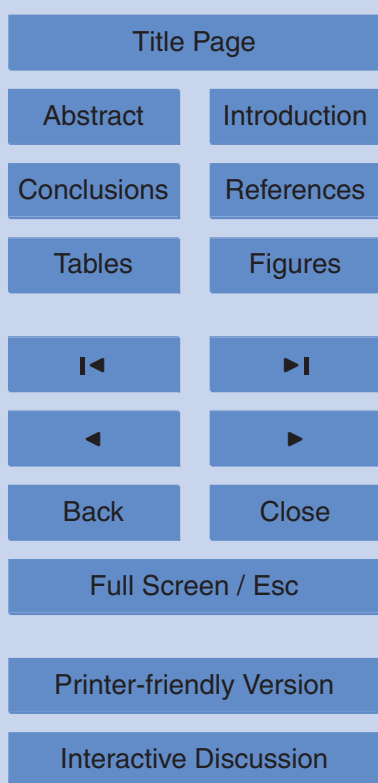




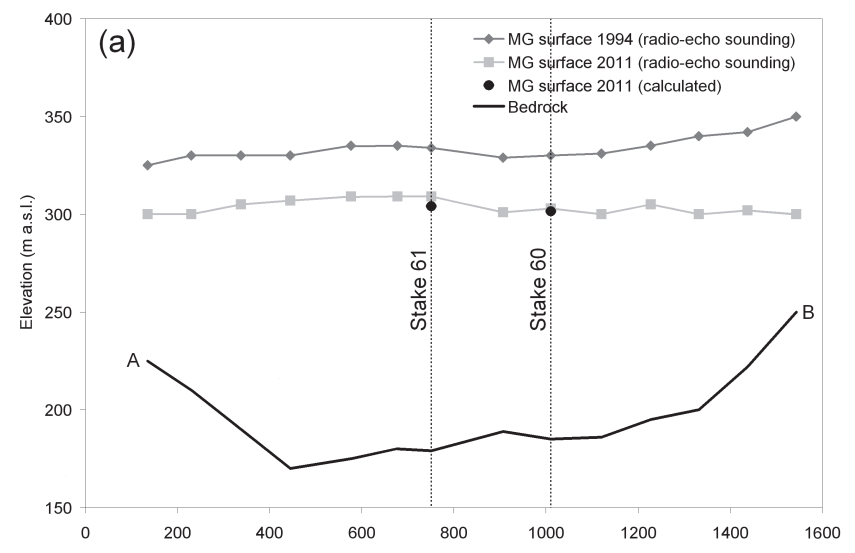

6, 4387-4415, 2012

\section{Thinning and slowdown of Greenland's Mittivakkat Gletscher}

S. H. Mernild et al.

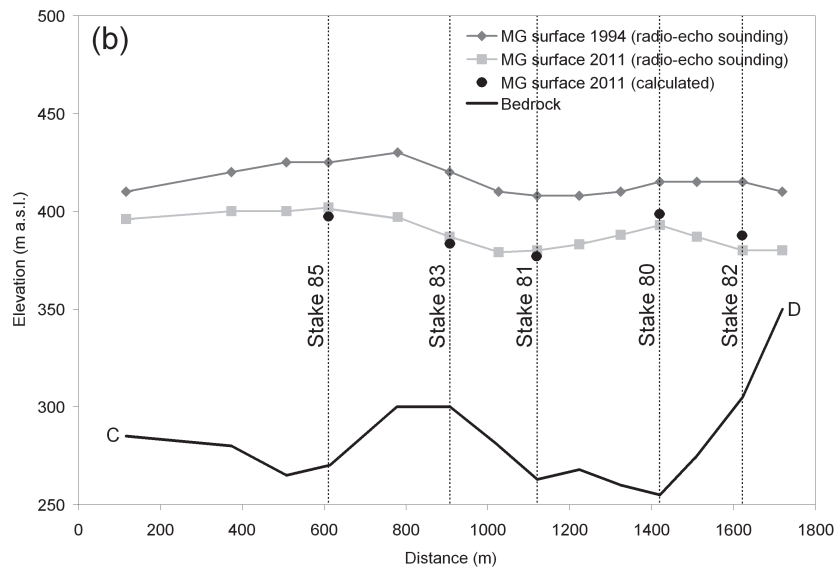

Title Page

Abstract

Conclusions

Tables

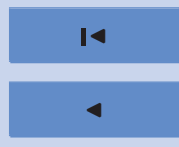

Back
Introduction

References

Figures

- I

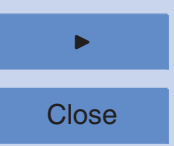

Full Screen / Esc

Printer-friendly Version

Interactive Discussion

Fig. 2. A comparison between the 2011 calculated mean MG thickness and the 2011 and 1994 monopulse radio-echo sounding estimated mean thicknesses at two cross-section locations in the ablation area: (a) at around $300 \mathrm{~m}$ a.s.l.; and (b) at around $400 \mathrm{~m}$ a.s.l. See Fig. $6 \mathrm{c}$ for approximate locations of the cross-sections. 

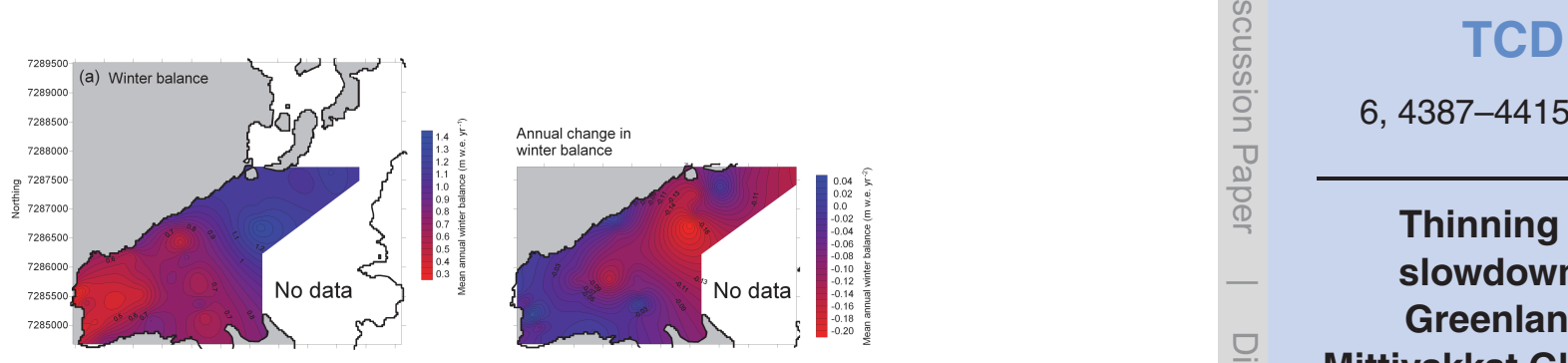

$6,4387-4415,2012$
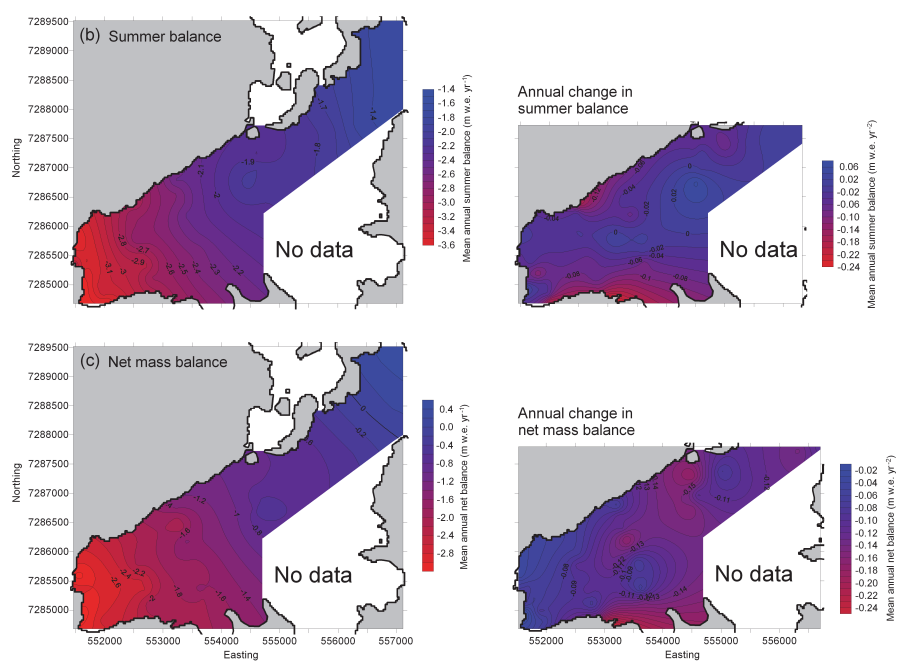

Fig. 3. Annual mass balance distributions and changes at Mittivakkat Gletscher: (a) mean winter mass balance and annual change (blue-red shades); (b) mean summer mass balance and annual change; and (c) net annual mass balance and annual change for 1996/1997 through 2010/2011. The white area has no data, and the margin is based on Landsat 7 ETM+ Mosaic imagery - 14 August 2011 and 1 August 2009.

Thinning and slowdown of Greenland's Mittivakkat Gletscher

S. H. Mernild et al.

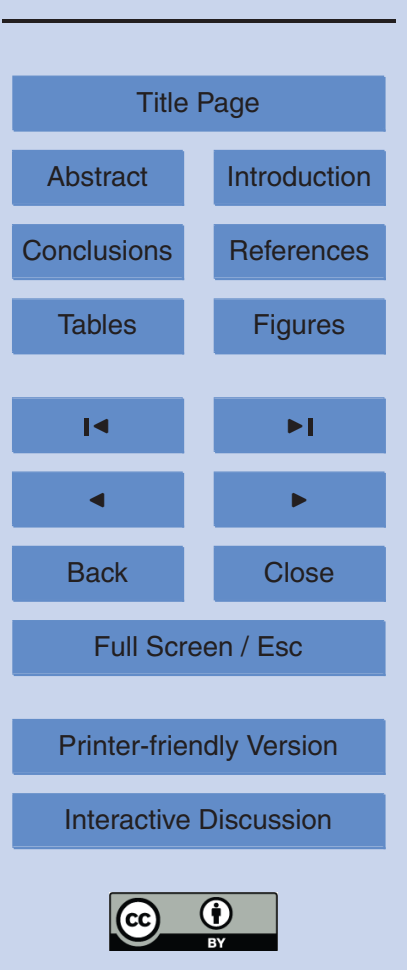




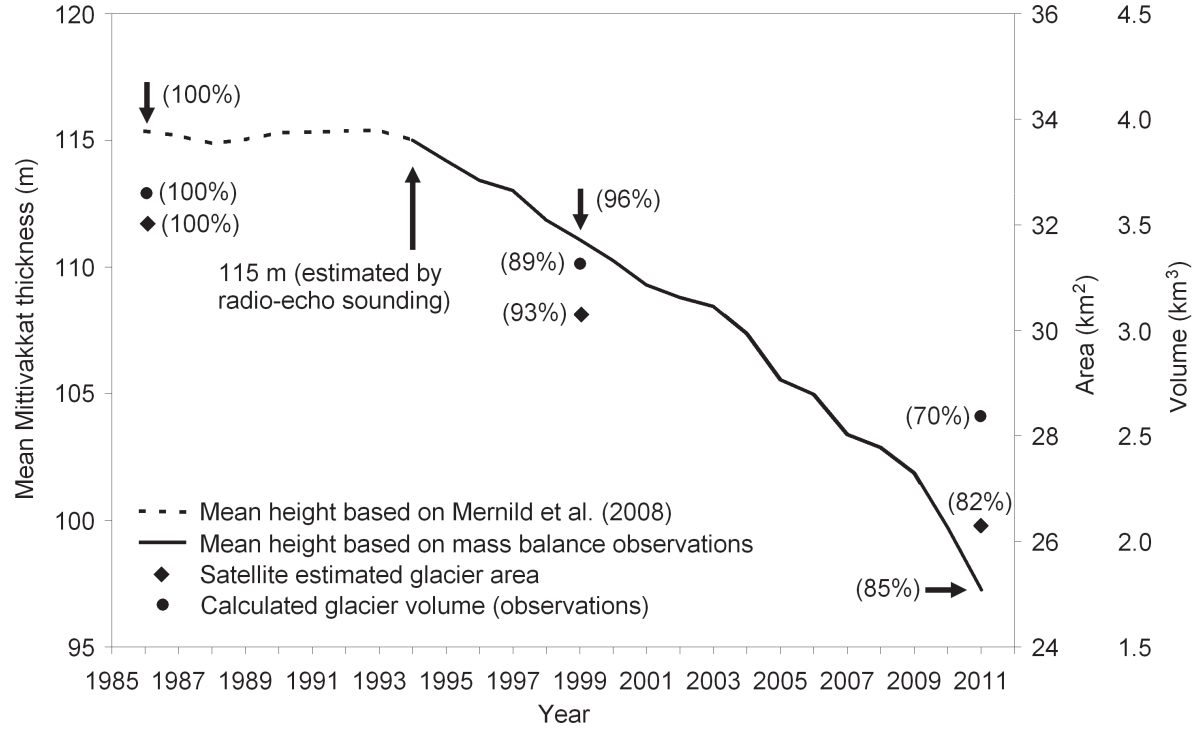

Fig. 4. Time series of estimated mean thickness (line), area (diamonds; Mernild et al., 2012), and volume (circles) for the Mittivakkat Gletscher. The dashed time series is estimated based on Mittivakkat Gletscher net mass balance calculations (Mernild et al., 2008b). The percent of 1986 Mittivakkat Gletscher mean height, area, and volume (the 1986 values were set to $100 \%$ ) are shown in brackets.
Thinning and slowdown of Greenland's Mittivakkat Gletscher

S. H. Mernild et al.

\section{Title Page}

\section{Abstract}

Introduction

Conclusions

References

Tables

Figures

14

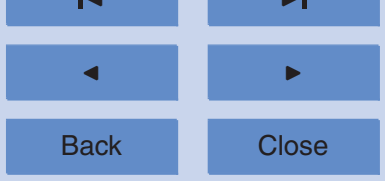

Full Screen / Esc

Printer-friendly Version

Interactive Discussion 


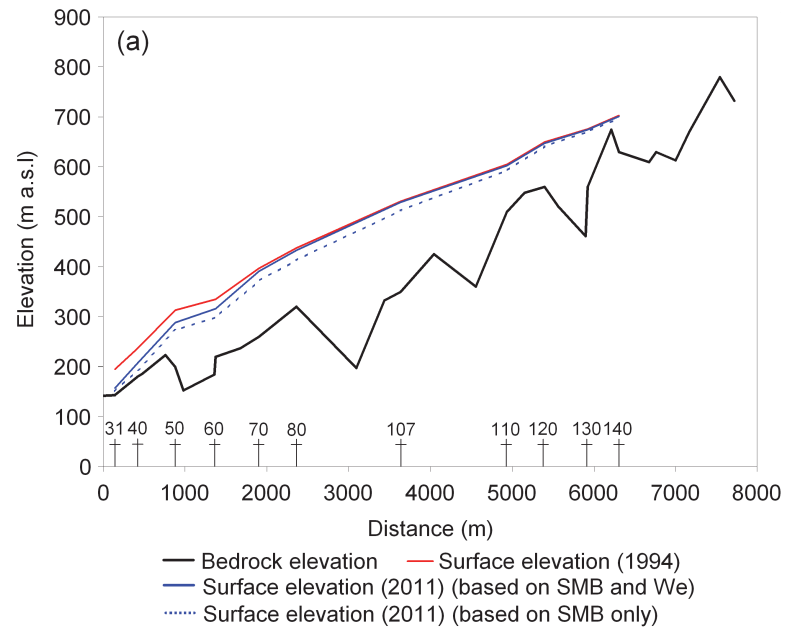

\section{TCD}

6, 4387-4415, 2012

\section{Thinning and slowdown of Greenland's \\ Mittivakkat Gletscher}

S. H. Mernild et al.

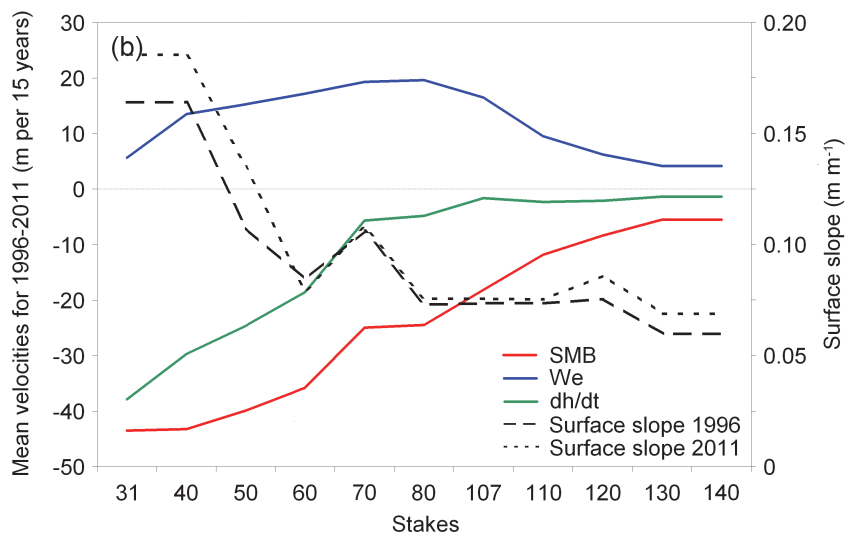

Title Page

Abstract

Conclusions
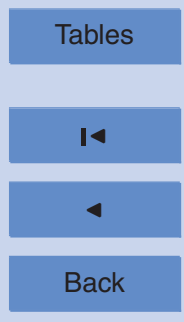

Full Screen / Esc

Printer-friendly Version

Interactive Discussion

was calculated with and without vertical velocity $\left(w_{e}\right)$, showing the positions of stakes 31 to 140; and (b) longitudinal mean surface slope for 1996 and 2011, SMB, $W_{\mathrm{e}}$, and $\mathrm{d} h / \mathrm{d} t$. 

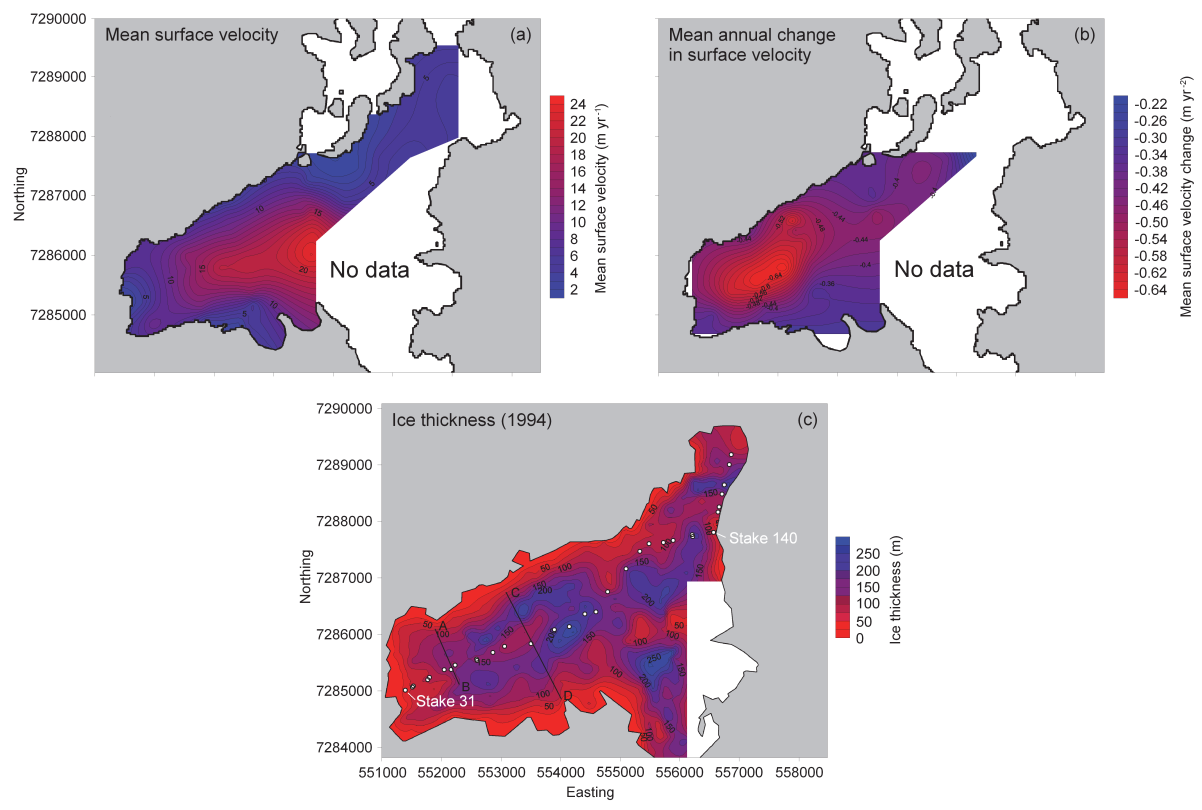

Fig. 6. Mittivakkat Gletscher (a) mean annual surface velocity; (b) mean surface velocity change from 1996/1997 to 2010/2011; and (c) ice thickness based on radar observations in 1994 (Knudsen and Hasholt, 1999) including the location of the longitudinal profile (white circles) (illustrated in Fig. 5a, b) and the two cross-section profiles (illustrated in Fig. 2). The locations of stake 31 and 140 are marked. No observations were made in the southeastern part of the glacier since this is a heavily crevassed area. The white area has no data, and the margin in (a) and (b) is based on Landsat 7 ETM+ Mosaic imagery - 14 August 2011 and 1 August 2009, and in (c) from GPS observations.

\section{TCD}

$6,4387-4415,2012$

Thinning and slowdown of

Greenland's

Mittivakkat Gletscher

S. H. Mernild et al.

Title Page

Abstract

Introduction

Conclusions

References

Tables

Figures

14

$\rightarrow$

4

Back

Close

Full Screen / Esc

Printer-friendly Version

Interactive Discussion 


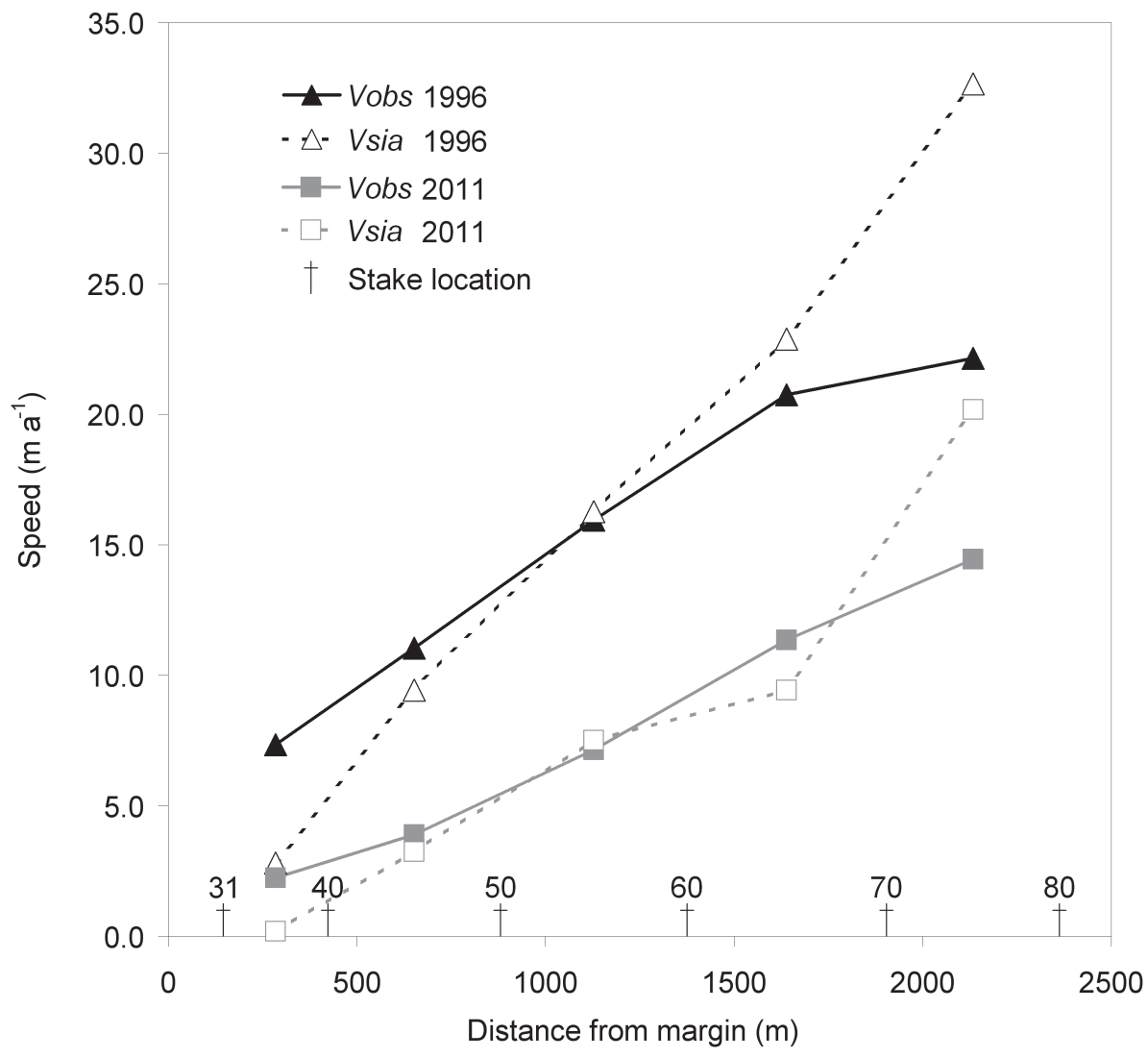

$6,4387-4415,2012$

Thinning and slowdown of Greenland's Mittivakkat Gletscher

S. H. Mernild et al.

Title Page

Abstract

Introduction

Conclusions

References

Tables

Figures

14

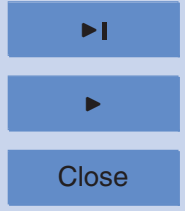

Back

Full Screen / Esc

Fig. 7. Observed $\left(v_{\text {obs }}\right)$ and calculated ( $v_{\text {sia }}$, Eq. 4) surface velocities for 1996 and 2011 along a longitudinal profile (Fig. $6 \mathrm{c}$ ) through the ablation zone. Each point is midway between two stake locations which are identified by $\dagger$ symbols.

Printer-friendly Version

Interactive Discussion 


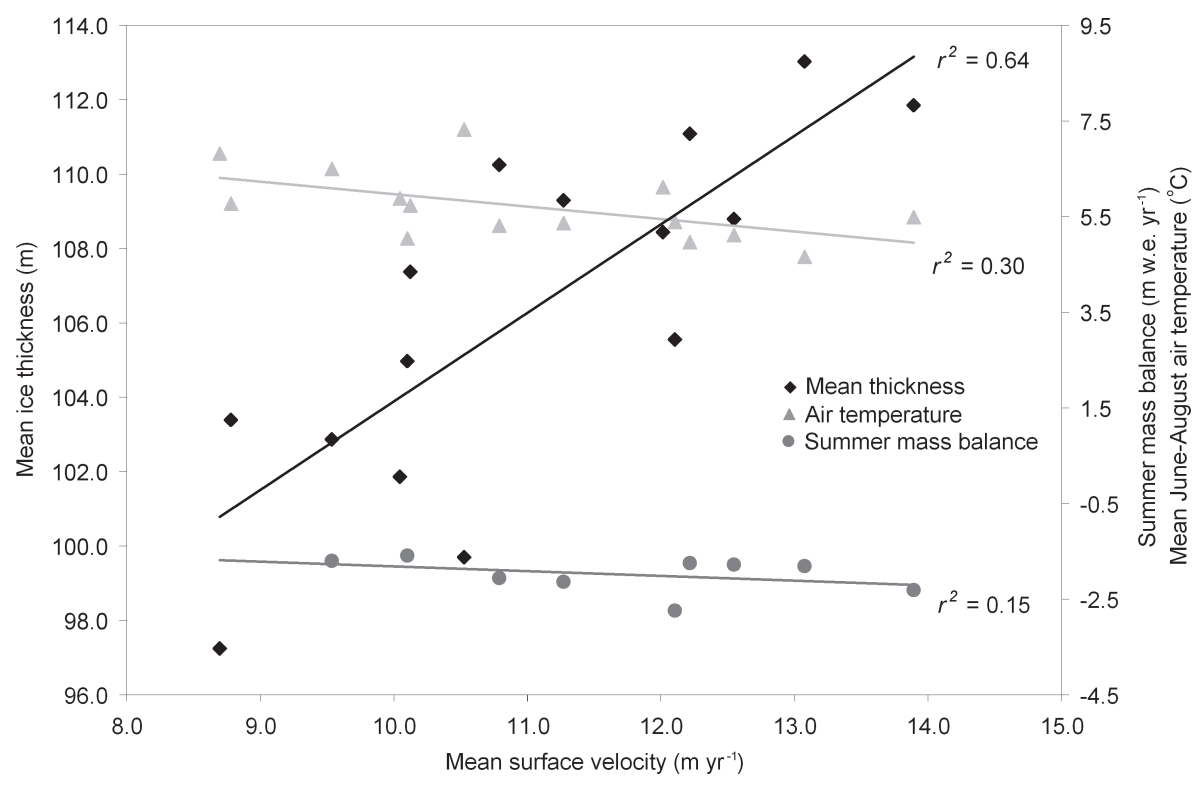

Fig. 8. Linear relation between Mittivakkat Gletscher mean annual surface velocity and mean ice thickness (black diamonds) estimated from stake observations; observed summer mass balance (dark gray circles); and observed mean JJA air temperature at Station Nunatak (light gray triangles) from 1996-2011.

\section{TCD}

$6,4387-4415,2012$

Thinning and slowdown of Greenland's Mittivakkat Gletscher

S. H. Mernild et al.

Title Page

Abstract

Introduction

Conclusions

References

Tables

Figures

14

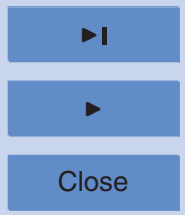

Back

Full Screen / Esc

Printer-friendly Version

Interactive Discussion 


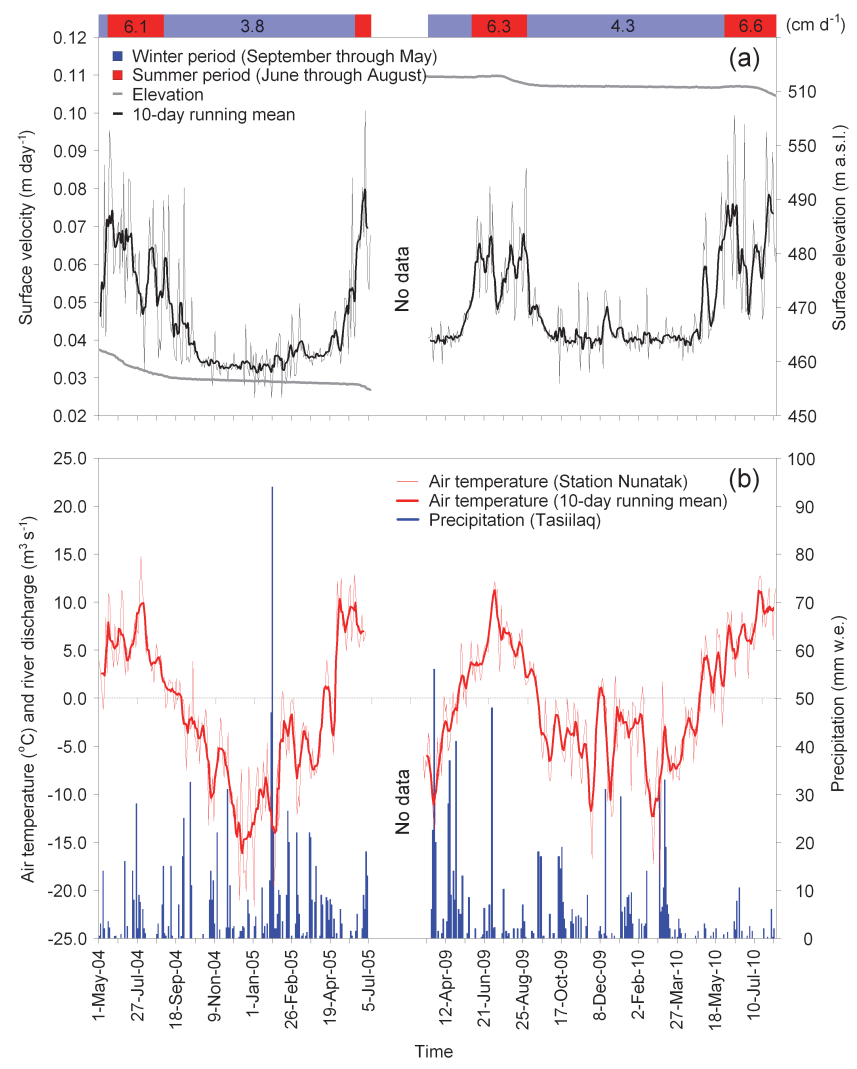

\section{Thinning and slowdown of Greenland's Mittivakkat Gletscher}

S. H. Mernild et al.

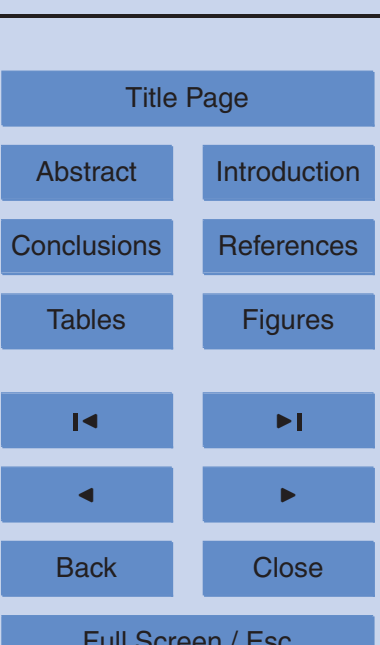

Fig. 9. (a) Observed Mittivakkat Gletscher seasonal surface velocity at the GPS station. Between 2005 and 2009 the GPS station was moved to a higher elevation on the glacier (see black and white diamonds on Fig. 1 for locations). Also, the mean seasonal surface velocities are shown for the winter (September through May; marked with light blue at the top of the figure) and summer (June through August, marked with red); and (b) observed air temperature at Station Nunatak and observed precipitation (uncorrected) at Station Tasiilaq.

\section{Full Screen / Esc}

Printer-friendly Version

Interactive Discussion

Discussion 